\title{
CONTROL OF BROWN RAT (Rattus norvegicus) ON A DAIRY FARM IN SERBIA
}

\author{
S. Đedovic' ${ }^{1}$, M. Vukša ${ }^{1}$, M. M. Petrović ${ }^{2}$, J. Bojkovski ${ }^{3}$, I. Pavlović ${ }^{4}$, G. \\ Jokić $^{\prime}$, B. Stojnić ${ }^{5}$
}

${ }^{1}$ Laboratory of Applied, Institute of Pesticides and Environmental Protection, Banatska 31b, Belgrade, Serbia

${ }^{2}$ Institute for Animal Husbandry, Autoput 16, Belgrade, Serbia

${ }^{3}$ University of Belgrade, Faculty of Veterinary Medicine, Bulevar oslobođenja 18, Belgrade, Serbia

${ }^{4}$ Scientific Institute of Veterinary Medicine of Serbia, Belgrade, V. Toze 14, Belgrade, Serbia

${ }^{5}$ University of Belgrade, Faculty of Agriculture, Nemanjina 6, Belgrade, Serbia

Corresponding author: Suzana.Djedovic@pesting.org.rs

Original scientific paper

Abstract: Rattus norvegicus is a synanthropic species living almost exclusively around facilities for keeping domestic animals. This three-year research focused on options for reducing economic damage caused by this rodent species in stables for heavy milking cows by testing preparations with active substances of various origin. It involved an environmentally friendly product based on sodium selenite $0.1 \%$, a cholecalciferol-based natural product $0.75 \%$, as well as anticoagulant rodenticides containing the active substances bromadiolone $0.005 \%$ and brodifacoum $0.005 \%$. These preparations were formulated as granules, plate bait or grain bait. The environmentally friendly sodium selenite product achieved $76.2 \%$ efficacy in the first year of research, $70 \%$ in the second, and $67.5 \%$ in the third. The synthetic products based on bromadiolone and brodifacoum demonstrated high efficacy in all of the three experimental years and in all three formulations. The cholecalciferol rodenticide had $71.4 \%$ efficacy in the first year, $68 \%$ in the second, and $67.7 \%$ in the third. The data show that the environmentally safe product had a lower efficacy due to high rodent abundance and inadequate epidemiological conditions existing on the farm of heavy milking cows, while the bromadiolone and brodifacoum-based products achieved high efficacy.

Key words: Rattus norvegicus, sodium selenite, efficacy, farm of heavy milking cows

\section{Introduction}

Brown rat (Rattus norvegicus) is one of the most important pests in a group of small rodents, and it is associated with other wild animals while living in the closest neighbourhood of man and his environment (Bojkovski et al. 1991). It is 
almost invariably found on cattle farms, where it builds a simple system of underground corridors and makes $6-10 \mathrm{~cm}$ holes in walls. Rats are transmitters of a number of infectious diseases to domestic animals (Morita, 1985). The chain of toxicoinfection on a farm includes the farmers' food and clothes, infected by rat urine and feces, as well as hay and silage feed for cattle and direct rat bites. Contaminated or poorly stored forage is a health hazard for animals (Daniels et al., 2003).

Singleton et al. (Singleton et al.,1999) presented the environmental benefits of a strategy of brown rat control by setting up points of attraction, i.e. a system of trap-barriers rich in different food sources. A research has shown that facilities housing different categories of animals are highly suitable places for rats to spread into from surrounding environments as food sources are abundant there. This research focused on the control of brown rat (Rattus norvegicus) on a farm with a free range system of herd raising by application of an environmentally friendly product based on selenium and on comparing the results with the effectiveness of anticoagulant products and a cholecalciferol-based natural product, considering the aspect of animal hygiene.

The micronutrient selenium used in forage in the amount of $0.1 \mathrm{mg} / \mathrm{kg}$ is the optimum rate that helps protect health and improve productive and reproductive characteristics of dairy cows. Calves fed after birth on milk supplemented with selenium are better protected from antioxidative substances (Joksimović-Todorović, 2007). The mechanism of activity of sodium selenite is based on a replacement of the S-H group of functional cellular proteins with the S-S bond, toxicity depends on the chemical form of selenium, and the selenite is more toxic than selenate. Target organs include: respiratory organs, CNS, cardiovascular system, digestive system and skin. Lethal effect is achieved by a single dose and resistence is not possible.

Introduction of these products would help reduce excessive use of the anticoagulant products bromadiolone and brodifacoum, as well as frequent intoxications of humans and domestic animals.

Cholecalciferol-based (vitamin D) products belong to a group of fast-acting, acute poisons, whose mode of activity is based on an extensive absorption of intestinal calcium and intensified resorption from bones, which leads to calcium and phosphorus sedimentation in all soft tissues and broodstream, and results in heart, blood vessels and kidney damage. The process of calcification is very fast in the group of mice rodents, lasting no more than several days (Merck Veterinary Manuel, 2011). The primary role of cholecalciferol is efficient control of rodent pest populations that are resistent to anticoagulants (Marshall, 1984).

Cholecalciferol use has been limited in Serbia (Službeni glasnik RS, 2009), which has narrowed the choice of available rodenticides.

The second generation anticoagulant rodenticides based on bromadiolone and brodifacoum are slow-acting poisons whose mechanism of activity is based on 
preventing the synthesis of factor IX required for blood clotting, which results in animal bleeding to death because its blood can no longer coagulate. Resistence has been observed and reported (Lund, 1984, Myllymaki, 1995).

This research focused on the control of brown rat (Rattus norvegicus) on a farm with a free range system of herd raising by application of an environmentally friendly product based on selenium and on comparing the results with the effectiveness of anticoagulant products and a cholecalciferol-based natural product, considering the aspect of animal hygiene.

\section{Materials and Methods}

A three-year research was conducted on a farm of heavy milking cows that are held in a free range system, and trials were set up in all available facilities: cow stables, milking parlour, calves' stable and silo. Before setting up trials and chosing rodenticides, we examined the level of invasiveness by rodents, their paths and numbers. Brown rat (Rattus norvegicus) presence was confirmed visually. The appearance of feces that were found in the facilities further confirmed its presence.

All rodenticides were tested in these trials in different formulations and they have different mechanisms of activity. The products EKOSTOP, EKOSEL and MAMAK B (all in three formulations: granules, peletes, soft bait) were manufactured by DOO CIKLONIZACIJA, Primorska 76, Novi Sad, Serbia, while the active ingredient brodifacoum and the product RATTACK were manufactured by DOO DUOCHEM, Ruzveltova 36, Belgrade, Serbia.

The standard method PP 1/114(2) (EPPO, 1999) was applied in all trials. All treatments were made in the same period to reduce risks from various timedependent factors (such as weather conditions or the loading and unloading storage goods). Poisons were laid after previously placing placebo baits to carry out method of census. Portions of $200 \mathrm{~g}$ of grain per box were laid down placed on the first day of census. Rodent abundance was assessed using the C-30 method (World Health Organization) or the transect method $(E P P O, 1992)$ at the beginning and 10 days after the beginning of trial. Placebo bait was laid at 10 spots in each facility over a period of 5 days. Each box was marked by an ordinal number, name of product and amount of bait and arranged at 3-5 m distance from each other. To avoid unwanted poisoning, the test products were labelled according to HACCP standards (Bokelman,1996). The amount of consumed bait was checked on a daily basis over a period of ten days. Bait was added as needed.

Data on palatability and biological effectiveness of products under laboratory conditions and rodenticide efficacy against rodents in storage facilities were calculated using Abbott's formula (Abbott, 1925). 


\section{Results and Discussion}

Brown rat was found in high abundance (Tables 1, 2, 3) on the dairy farm as a result of its technology of construction, external unprotectedness and inadequate sanitary and epidemiological conditions.

Figure 1 shows a ten-day intake of products based on different active ingredients and formulated as granules (GB) in the first year of research.

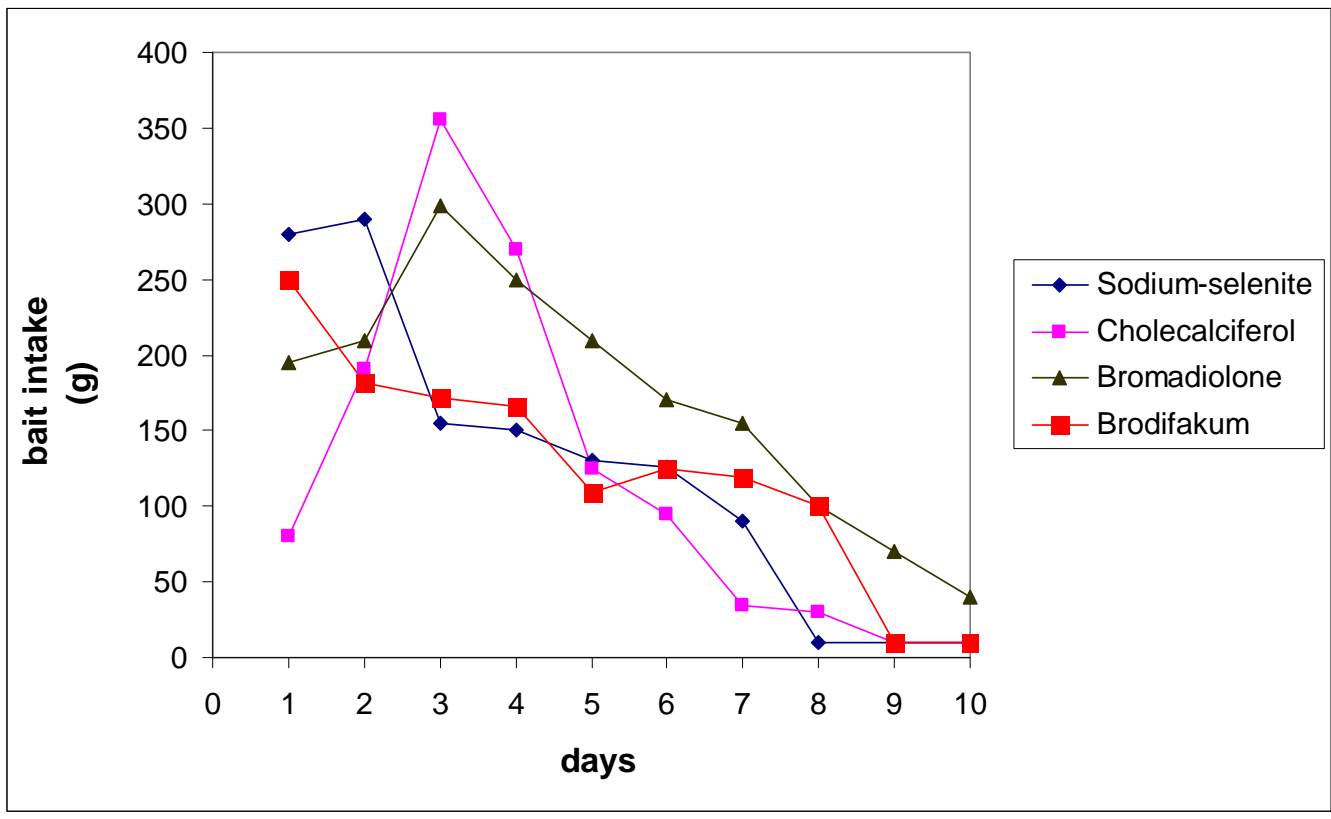

Figure 1. Ten-day intake of products containing different active ingredients in granule (GB) formulations on a dairy farm in the first year of research

The granule formulation of all products was tested in the first year of research. The sodium selenite product was less palatable due to its relatively poor organoleptic properties. Its palatability was highest in the first two days, with $280 \mathrm{~g}$ eaten on the first and $290 \mathrm{~g}$ on the second day. Over the next several days, the amount of bait consumed continued to decrease. The product should be improved in terms of attractiveness, especially for situations in which animals have a wide selection of food sources on a farm. High efficacy of this product was observed but the experimental data reflected the known fact that selenium is highly degradable.

The fast-acting cholecalciferol was found to have been consumed the least, which may be due to the fact that vitamin $\mathrm{D}$ concentration in a bait and its palatability are inversely proportionate. Meehana (Meehan, 1984) had observed 
that a $0.1 \%$ concentration of cholecalciferol had a repelent effect on rodents. The highest daily intake was observed on the third day after the trial started and it decreased drastically and continually throughout the trial. Symptoms of poisoning occurred 24-48 $\mathrm{h}$ after intake.

Palatability of this product should also be improved, especially on farms where other food sources are also available.

The slow-acting rodenticides based on bromatiolone $(0.005 \%)$ and brodifacoum $(0.005 \%)$ demonstrated good palatability.

The most palatable product was bromadiolone in this year of research after ten days of consumption, and its efficacy was as high as $94.8 \%$ (Table 1). Intakes of both products decreased after seven days, which is consistent with out earlier data. Mortality had a peak between the fourth and seventh day of consumption.

Figure 2 shows a ten-day intake of products containing different active ingredients formulated as plate bait (PB) in the second year of experiment.

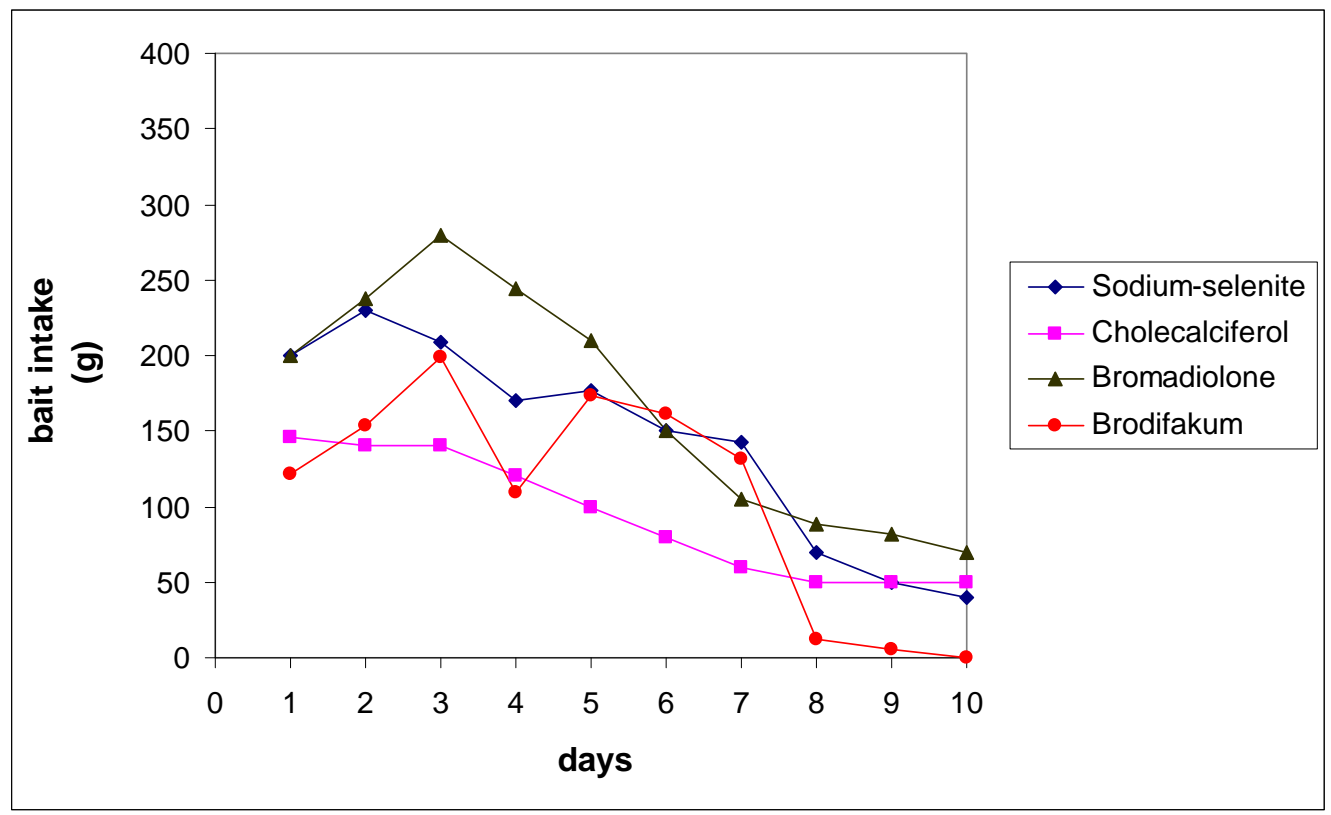

Figure 2. Ten-day intake of products containing different active ingredients in plate bait (PB) formulations on the dairy farm in the second year of research

Plate baits were tested in the second year of research. Brown rats consumed considerably greater amounts of sodium-selenite bait $(0.1 \%)$ and product palatability was satisfactory for the animals' organoleptic requirements. Efficacy 
was slightly lower (70\%) than it had been in the first year, which may be due to degradation of the active ingredient.

The intake of bait based on cholecalciferol $(0.075 \%)$ was lowest, only $936 \mathrm{~g}$. The ten-day consumption was even, slightly higher initially and then decreasing. Palatability was unsatisfactory and the product achieved lower efficacy than it had been observed in our earlier research. Bitter taste of this active ingredient makes the animals give it up easily and exchange it for other available food on the farm.

Slow-acting rodenticides based on bromadiolone $(0.005 \%)$ and brodifacoum $(0.005 \%)$ demonstrated better palatability in the second year, which may be due to a better choice of attractant for rats and the fact that bait was coated with fine transparent paper which causes curiosity in animals. We also found scattered bait filter bags around rat paths together with dead animals. Total intake of bromadiolone bait was $1667 \mathrm{~g}$, and of brodifacoum $1068 \mathrm{~g}$. However, the former bait again had lower efficacy than brodifacoum even though its amounts consumed were higher.

Figure 3 shows a ten-day intake of products with different active ingredients in grain bait $(\mathrm{AB})$ formulations in the third year of experiment.

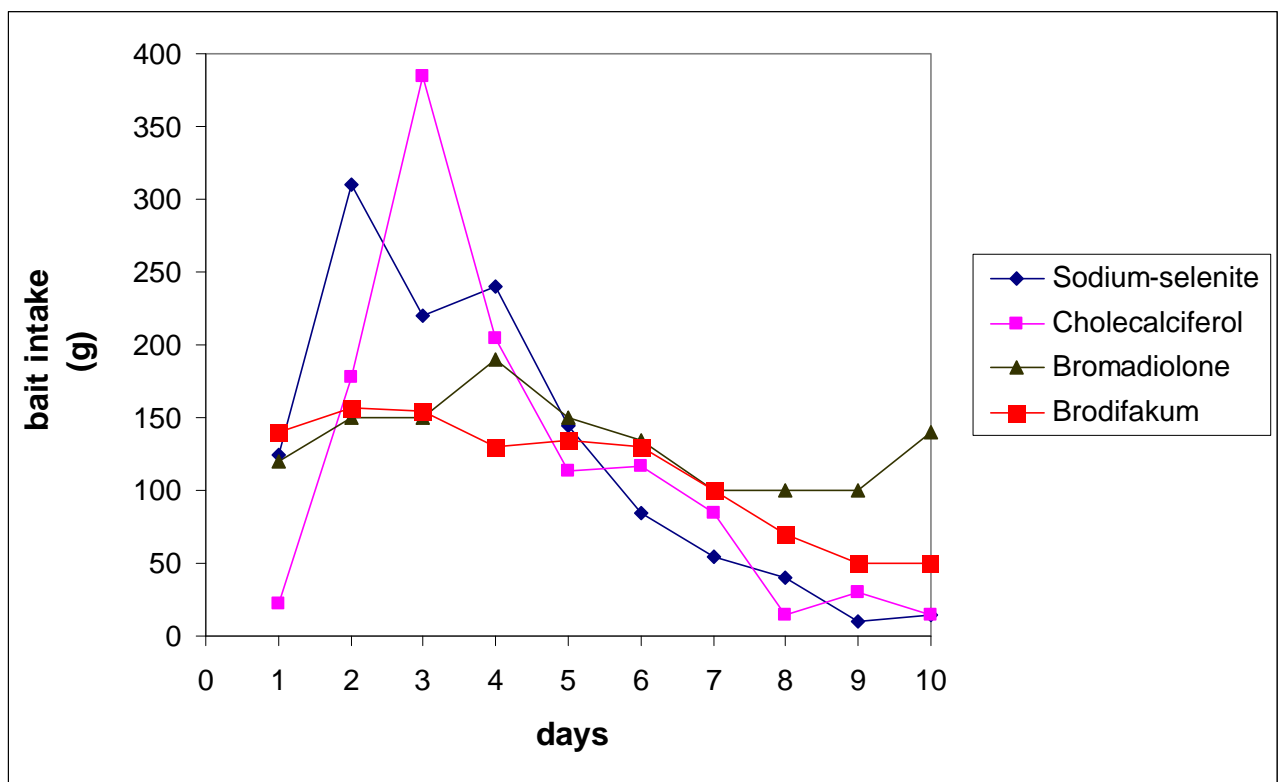

Figure 3. Ten-day intake of products containing different active ingredients in grain bait (AB) formulations on the dairy farm in the third year of research

Grain bait formulation was tested in the third year of research. Palatability of the sodium-selenite and cholecalciferol products was equal in the initial three days of trial. Their afficacies were also matching, $67.5 \%$ and $67.7 \%$, respectively 
(Table 3). Total intake of the environmentally safe bait with sodium selenite was $1251 \mathrm{~g}$ and of the cholecalciferol product $1200 \mathrm{~g}$. More animals died by eating bait that contained sodium-selenite than cholecalciferol bait. It confirms our earlier findings that sodium-selenite is highly toxic, and our future research will be focused on improving its organoleptic properties to increase attractiveness.

Regarding efficacy and palatability of the anticoagulant products, data in the third year of experiment confirmed consistency with those for the previous two years, $95 \%$ efficacy was achieved by bromadiolone, and $100 \%$ by brodifacoum (Table 3). The anticoagulant brodifacoum had the best attractiveness, good palatability and the best efficacy throughout the three-year period of research. An explanation of this may be the fact that its use had been limited in our country in the past, so that resistance has not yet developed. Its palatability is especially favourable. Palatability of the bromadiolone product was better in granules and plate bait (Figures 1 and 2) than in grain bait (Figure 3).

Tables 1,2 and 3 show efficacy data for the tested products with their different active ingredients and different formulations.

Table 1. Product efficacy in the first year of research and estimated brown rat number

\begin{tabular}{|c|c|c|c|c|c|}
\hline \multirow{2}{*}{ Species } & \multirow{2}{*}{$\begin{array}{c}\text { Active ingredient } \\
\text { (product formulation) }\end{array}$} & Bait intake & \multicolumn{2}{|c|}{ Estimated rat number } & Efficacy \\
\cline { 4 - 5 } & $(\mathrm{g})$ & Beginning & End & $\%$ \\
\hline \multirow{3}{*}{$\begin{array}{c}\text { Rattus } \\
\text { norvegicus }\end{array}$} & Sodium selenite (GB) & 1251 & 42 & 10 & 76.2 \\
\cline { 2 - 5 } & Cholecalciferol(GB) & 1200 & 28 & 8 & 71.4 \\
\cline { 2 - 5 } & Bromadiolone (GB) & 1699 & 57 & 3 & 94.8 \\
\cline { 2 - 5 } & Brodifacoum (GB) & 1242.5 & 43 & 0 & 100 \\
\hline
\end{tabular}

Table 2. Product efficacy in the second year of research and estimated brown rat number

\begin{tabular}{|c|c|c|c|c|c|}
\hline \multirow{2}{*}{ Species } & $\begin{array}{c}\text { Active ingredient } \\
\text { (product formulation) }\end{array}$ & Bait intake & \multicolumn{2}{|c|}{ Estimated rat number } & Efficacy \\
\cline { 4 - 6 } & $(\mathrm{g})$ & Beginning & End & $\%$ \\
\hline \multirow{3}{*}{$\begin{array}{c}\text { Rattus } \\
\text { norvegicus }\end{array}$} & Sodium selenite (PB) & 1438 & 50 & 15 & 70 \\
\cline { 2 - 6 } & Cholecalciferol(PB) & 936 & 25 & 8 & 68 \\
\cline { 2 - 6 } & Bromadiolone (PB) & 1667 & 55 & 3 & 94.5 \\
\cline { 2 - 6 } & Brodifacoum (PB) & 1068.5 & 38 & 0 & 100 \\
\hline
\end{tabular}

Table 3. Product efficacy in the third year of research and estimated brown rat number

\begin{tabular}{|c|c|c|c|c|c|}
\hline \multirow{2}{*}{ Species } & Active ingredient & Bait intake & \multicolumn{2}{|c|}{ Estimated rat number } & Efficacy \\
\cline { 4 - 6 } & (product formulation) & $(\mathrm{g})$ & Beginning & End & $\%$ \\
\hline \multirow{3}{*}{$\begin{array}{c}\text { Rattus } \\
\text { norvegicus }\end{array}$} & Sodium selenite (AB) & 1245 & 40 & 13 & 67.5 \\
\cline { 2 - 6 } & Cholecalciferol (AB) & 1065 & 31 & 10 & 67.7 \\
\cline { 2 - 6 } & Bromadiolone (AB) & 1235 & 40 & 2 & 95 \\
\cline { 2 - 6 } & Brodifacoum (AB) & 1115 & 39 & 0 & 100 \\
\hline
\end{tabular}


The environmentally friendly product based on sodium-selenite $(0.1 \%)$ demonstrated a satisfactory efficacy. It was $76.2 \%$ in the first year, $70 \%$ in the second and $67.5 \%$ in the third (Tables 1,2,3). Better efficacy results could be achieved by selecting the most viable attractant. Our own research so far has shown high toxicity of this active ingredient, but little effort has been made so far to improve its attractiveness and stability.

The cholecalciferol product was found to be less effective in its three examined formulations in the three years of this researchthan it had been recorded in our previous studies, namely 83-89\% (Vukša et al., 2006., Đedović et al., 2011), and in reports by other authors (Quy et al., 1995). The data possibly reflect the fact that this active ingredient has a bitter taste which is unacceptible to the brown rat. In addition to that, the farm had other food sources.

Bromadiolone granules and plate baits were found to have greater palatability (Figures 1 and 2) than the product's grain bait formulation (Figure 3), but all formulations achieved an efficacy of around 95\%, which indicates that cumulative effects of this active ingredient had the same level of toxicity over a period of 4-7 days (possibly because resistence has not developed). Rowe et al. (1981) had reported bromadiolone efficacy ranging from $92.7-100 \%$ against the house mouse on farms. Experiments so far and our overall experience have indicated an extended activity of this active ingredient and animals were dying even 10 days after treatment. Lower efficacy of these products is indicative of resistance.

In this research, the rodenticides based on brodifacoum achieved $100 \%$ efficacy (Tables 1, 2 and 3). Attractiveness was good in all three years of experiment.

\section{Conclusion}

In our research, the sodium-selenite products had lower palatability, so that suitable attractants need to be added to improve its organoleptic properties, and yellow or green colour should be used because rats are particularly sensitive to them. These products are highly toxic and laboratory research has confirmed it.

Cholecalciferol rodenticides were consumed most reluctantly due to their bitter taste. They belong to a group of fast-acting poisons that have lethal effect within 24 hours, but their negative side is that they have to be kept at low temperature or fast degradation will occur. Our research has shown them as the least effective.

The two anticoagulant products demonstrated good palatability and efficacy in all tested formulations. Those are slow-acting poisons that have cumulative effect which requires some time after intake. They should be carefully used because of possible resistance. 
In this three-year research, product formulation was not found to have significantly affected palatability for the brown rat.

We recommend regular three-month checks on farms with particularly high infestations, poor hygiene and epidemiological conditions, and six-month checks on farms with satisfactory conditions. Also, population abundance of brown rat should be monitored on a monthly basis by setting up live-traps and marking captured animals.

\section{Acknowledgment}

This study was carried out as part of Project III 4608 "Development of an integrated system of management of harmful organisms on plants, aiming to overcome resistance and improve food quality and safety (2011-2014)“" which was financially supported by the Ministry of Education, Science and Technological Development of the Republic Serbia.

\section{Prilog poznavanju suzbijanja sivog pacova (Rattus norvegicus) na farmi mlečnih krava}

S. Đedovic, M. Vukša , M. M. Petrović, J. Bojkovski, I. Pavlović, G. Jokić, B. Stojnić

\section{Rezime}

Rattus norvegicus gotovo uvek živi u objektima namenjenim za gajenje domaćih životinja i kao sinanotropna vrsta prisutan je u čovekovoj najbližoj okolini. Predmet naših trogodišnjih istraživanja je alternativa smanjenja ekonomskih šteta koju pričinjava ovaj glodar u stajama farmi visoko-mlečnih krava, primenom preparata na bazi aktivnih materija različitog porekla.

U eksperimentima je korišćen ekološko prihvatljivi preparat na bazi natrijum-selenita $(0,1 \%)$, preparat prirodnog porekla na bazi holekalciferola $(0,75 \%)$ i antikoagulantni rodenticidi na bazi bromadiolona $(0,005 \%)$ i brodifakuma $(0,005 \%)$. mamka.

Primenjeni preparati su formulisani u obliku granula, obloženog i zrnastog

Ekološko prihvatljivi preparat na bazi natrijum-selenita je ispoljio efikasnost od $76,2 \%$ u prvoj godini istraživanja, u drugoj $70 \%$ i u trećoj godini $67,5 \%$. Sintetisani preparati na bazi bromadiolona i brodifakuma pokazali su visoku efikasnost $u$ sve tri godine ispitivanja za sve tri navedene formulacije. Rodenticid na bazi holekalciferola je ispoljio efikasnost od $71,4 \%$ u prvoj godini, u drugoj 
$68 \%$ i u trećoj $67,7 \%$. Rezultati istraživanja ukazuju da je zbog velike brojnosti glodara i neadekvatnih epidemioloških uslova na farmi visoko-mlečnih krava ispoljena slabija efikasnost ekološko prihvatljivog preparata dok su preparati na bazi bromadiolona i brodifakuma ispoljili visoku efikasnost.

\section{References}

ABBOTT W.S. (1925): A method of computing the effectiveness of an insecticide. J. Econ, Entomol, 18, 265-267.

BOJKOVSKI J., SOLDATOVIĆ B., NIKOLIĆ A. (1991): Cytogenetic observation on numerical and structural chromosome aberrations induced by environmental influence in mice of the genus Apodemus, Acta Veterinaria, 41, 56, 241-246.

BOKELMAN B. (1996): Quality Assurance and HACCP with Special Attention to Long Life Products.

DANIELS M.J., HUTSCHINGS M.R., GREIG A. (2003): „The risk of disease to livestock posed by contamination of farm stored feed by wildlife excreta". Michigan Bovine Tuberculosis Bibliography and Datubase. Paper 14.

ĐEDOVIĆ S., VUKŠA M., STOJNIĆ B., JOKIĆ G. (2011): Preparat na bazi selena i suzbijanje sinantropnih glodara u objektima u poljoprivredi. Pestic. Fitommed., 26, 3, 265-270.

EPPO (1992): Guide for the officacy evaluation of rodenticides, No. 169, EPPO Bull.,22,181-202.

EPPO, 1999: Guideline for the efficacy evaluation of rodenticides: Field tests against synanthropic rodents (Mus musculus, Rattus norvegicus i R. rattus) - PP 1/114(2), in EPPO 1999. Guidelines for the efficacy evaluation of Plant Protection Products. Rodenticides, 1, European and Mediterranean Plant Protection Organization, Paris, pp. 83-144.

JOKSIMOVIĆ-TODOROVIĆ M., DAVIDOVIĆ V., HRISTOV S., STANKOVIĆ B., BOJKOVSKI J. (2007): Deficit selena kod mlečnih krava., Zbornik naučnih radova Instituta PKB Agroekonomik, 13, 3-4, 41-46.

LUND M. (1984): Resistance to the second generation anticoagulant rodenticides. In: Proceedings of Eleventh Vertebrate Pest Conference. Sacramento, California (Ed. by D.O.Clarck), pp. 89-94.

MARSHALL E.F. (1984): Cholecalciferol: a unique toxicant for rodent control. Proc. $11^{\text {th }}$ Vertebr. Pest Conf., 95-98.

MERCK VETERINARY MANUEL (2011): Rodenticide Poisoning Introduction, Whitehouse Station, NJ USA.

MEEHAN A.P. (1984): Rats and Mice-their biology and control. Rentokil Ltd., East Grinstead, W. Sussex, 383 pp. 
MORITA C.H., MATSUURA Y., MORIKAWA S.H., KITAMURA T (1985): Age dependent transmission of hemoragic fever with renal syndrome (HFRS) virus in rats. Arch. Virol., 85, 145.

MYLLYMAKI A. (1995): Anticoagulant resistance in Europe: Appraisal of the data from 1992 EPPO questionnaire. Pestic. Sci., 43, 69-72.

ROWE F.P., PLANT C.J., BRADFIELD A. (1981): Trials of the anticoagulant rodenticides bromadiolone and difenacoum against the house mouse (Mus musculus L.). Journal of Hygiene, London 81, 171-177.

QUY R.J., COWAN D.P., PRESCOTT C.V., GILL E.J., KERINS G.M., DUNSFORT, G., JONES A., MACNICOL A.D. (1995): Control of a Population of Norway Rats Resistant to Anticoagulant Rodenticides. Pestic. Sci., 45, 247-256.

SINGLETON G.R., HINDS L.A., LEIRS H., ZHANG Z. (1999): Ecologically based rodent menagment ACIAR, Canberra, Australia..

SLUŽBENI GLASNIK RS BR. 36/09 (2009): Lista zabranjenih hemikalija, pravilnik o uvozu i izvozu određenih opasnih hemikalija.

VUKŠA M., DRAGANIĆ M., ĐEDOVIĆ S., JOKIĆ G. (2006): Laboratory effects and efficacy of a Se-based rodenticide in controlling rodents in storage facilites. Proceedings of the $9^{\text {th }}$ International Working Conference on Stored Product Protection, Campinas, Sao Paulo, Brazil, 920-925.

Received 25 July 2012; accepted for publication 17 September 2012 